\title{
Romatoid Artritli Kadın Hastalarda Seksüel Disfonksiyonun Değerlendirilmesi
}

\author{
Evaluation of Sexual Dysfunction in Females With Rheumatoid Arthritis
}

\author{
Sibel Arslan CEBECl, Hakan GENÇ*, Hatice Rana ERDEM**, Barış NACIR* , Aynur KARAGÖZ* \\ Sağlık Bakanlığı Kocaeli Derince Eğitim ve Araştırma Hastanesi, Fizik Tedavi ve Rehabilitasyon Kliniği, Kocaeli, Türkiye \\ Sağık Bakanlığı Ankara Eğitim ve Araştırma Hastanesi, Fiziksel Tıp ve Rehabilitasyon Kliniği, Ankara, Türkiye
}

\section{Özet}

Amaç: Romatoid Artrit (RA)'in kadınlardaki seksüel fonksiyona etkisini araştırmak ve normal popülasyonla karşılaştırmaktı.

Gereç ve Yöntem: Çalışmamıza 100 kadın RA hastası ile yaş ve vücut kütle indeksi eşleştirilmiş 45 sağlıklı kadın dahil edildi. RA'lı hastaların klinik parametreleri, günlük yaşamdaki sağlık durumları, fonksiyonel durumları, hastalık aktiviteleri, artiküler indeksleri, el kavrama güçleri, laboratuvar aktivite bulguları ve el, ayak, kalça ve dizlerindeki radyolojik hasar değerlendirildi. Her iki gruptaki hastalara Kadın Seksüel Fonksiyon Indeksi (KSFI) ve Beck Depresyon Ölçeği (BDÖ) sorgulama formları uygulandı. Hastalık parametreleri ile KSFI'nin total ve 6 parametresi (arzu, uyarılma, lubrikasyon, orgazm, tatmin ve ağrı) arasındaki ilişki analiz edildi.

Bulgular: Çalışmaya alınan 100 kadın RA hastasının yaş ortalaması $44,8 \pm 8,2$ yıl (21-60), 45 kadın kontrol bireyinin yaş ortalaması $44,7 \pm 8,5$ yıl (26-59) idi $(p>0,05)$. RA'lı hastalarda KSFI'nin tüm alt birim ve toplam skoru kontrol grubuna göre istatistiksel açıdan anlamlı olarak düşük bulundu (sırasıyla $p<0,001$ ve $p<0,001-p<0,01$ ). BDÖ skorları da RA'lı hastalarda belirgin olarak yüksekti $(p<0,001)$. RA'lı hastalarda hastalığın seyrini olumsuz etkileyen çoğu parametrenin seksüel fonksiyonları istatistiksel olarak anlamlı derecede negatif etkilediği tespit edildi. Regresyon analizi yapıldığında seksüel disfonksiyonun, ileri yaş, hastalık süresinin uzunluğu, yüksek fonksiyonel sınıf, yüksek sağlık statü skoru ve yüksek BDÖ skoru ile gösterdiği korelasyonların daha belirgin olduğu saptandı.

Sonuç: RA'ı kadın hastalar normal popülasyona göre daha sık seksüel disfonksiyon yaşamaktadırlar. Türk Fiz Tıp Rehab Derg 2012;58:36-46. Anahtar Kelimeler: Romatoid artrit,seksüel disfonksiyon

\section{Summary}

Objective: To investigate the influence of rheumatoid arthritis (RA) on sexual functioning in female patients and to compare the results with data from the general population.

Metarials and Methods: One hundred women with RA and 45 age- and body mass index-matched healthy women were included in the study. Clinical parameters, health status of the patients during activities of daily living, functional classifications of patients, activity of disease, scores of articular index, hand grip values, laboratory activity parameters and radiological damage at the hands, wrists, ankles, knees, and hips were evaluated. The Female Sexual Function Index (FSFI) and the Beck Depression Index (BDI) were used in both groups. Correlations between the disease parameters and the total score and individual scores of 6 domain structure of FSFI (desire, subjective arousal, lubrication, orgasm, satisfaction, and pain) were analysed.

Results: The mean age of the patients was $44.8 \pm 8.2$ (21-60) years and controls was $44.7 \pm 8.5$ (26-59) years ( $p>0.05)$. Total and subunit FSFI scores were significantly lower in RA group than in controls $(p<0.001, p<0.001$ to $p<0.01$, respectively). BDI scores were also significantly higher in $\mathrm{RA}$ group $(p<0.001)$. It was found that all parameters, which affecting the progress of disease, also had negative effects on sexual function in RA group. Regression analysis showed that the correlations between the sexual dysfunction and age (elderly), the duration of disease, high functional class, high health status score and high BDI score were more significant than the other parameters.

Conclusion: In this study, sexual dysfunction was found to be more frequent among RA patients than in the normal population. Turk J Phys Med Rehab 2012;58:36-46.

Key Words: Rheumatoid arthritis, sexual dysfunction 


\section{Giriş}

Romatoid Artrit (RA); nedeni bilinmeyen, sinoviyal hücre proliferasyon ve inflamasyonunun eklemde ilerleyici yıkıma yol açması ile karakterize kronik, otoimmün, sistemik, inflamatuvar bir hastalıktır. Kronik progresif hastalık, sıklıkla fonksiyonel kayba neden olarak sakatlıkla sonuçlanır, yaşam kalitesini bozar ve yaşam süresini kısaltır. Eroziv, simetrik eklem tutulumu klinik tablonun en önemli komponenti olmakla birlikte ekstra-artiküler bulgular değişen derecelerde, bazen belirgin olmak üzere artrite eşlik eder (1-3).

Kadın seksüel disfonksiyonu, biyolojik ve psikososyal komponentleri içeren çok nedenli ve çok yönlü medikal bir problemdir. Toplumsal taramalardan ve jinekoloji kliniklerinden elde edilen prevelansına ilişkin değişik çalışmalarda, \%30 ile \%76 gibi çok yüksek sayılar verilmektedir (4-6). Cinsel yaşam hakkında bilgiler son yirmi yılda artmaya başlamıştır. Bunun nedeni cinselliğin insan kimliğinin ve yaşamının önemli bir yönü olduğunun kabul edilmesi olabilir. 1975'de Dünya Sağlık Örgütü, kişiliğin ve hayatın kalitesini artırmak ve zenginleştirmek için cinsel hayatın somatik, emosyonel, entellektüel ve sosyal yönlerinin sağlıklı bütünleştirilmesinin önemine dikkat çekmiştir. Cinsel yeterlilik duygusunun kimliğimizin çekirdeğini oluşturduğuna inanılmaktadır (7).

RA bir çok komponenti olan heterojen bir hastalıktır. Primer olarak bir çok eklemi etkileyerek fonksiyonel kayba yol açar (1). Bununla birlikte bireyin sosyal, ekonomik, psikososyal ve seksüel yaşamını da etkiler (8). RA'lı kadın hastalarda gelişen seksüel disfonksiyon, organik ve/veya psikojenik kaynaklı olabilir (9). Hastanın özellikle vücut imajının etkilenmesi, kendine güvensizliği birlikte getirir ve partneriyle arasındaki ilişkiyi olumsuz yönde etkiler (10). Hastalığa bağlı gelişen depresyondan dolayı seksüel yaşam etkilenebilir. Seksüel disfonksiyon da kısır bir döngü şeklinde depresyonu artırabilir (11). Bunun dışında Sjögren sendromu ve akciğer tutulumu gibi ekstraartiküler organ tutulumları da hastanın seksüel performansını olumsuz yönde etkileyebilen durumlardır. Şu ana kadar kadınlarda RA ve seksüel disfonksiyon ilişkisini araştıran çok az sayıda çalışma vardır (12-14).

Bu çalışmanın amacı, bir çok komponenti olan RA hastalığının kadınlardaki seksüel disfonksiyonun her bir alt parametresine etkisini araştırmak ve normal popülasyonla karşılaştırmaktır.

\section{Gereç ve Yöntem}

Çalışmamıza, kliniğimize bağlı romatoloji polikliniğinde takip edilen ve American College of Rheumatology kriterlerine göre RA tanısı almış, cinsel olarak aktif 125 kadın hasta dahil edilmiştir. Hastaların klinik değerlendirmesinde kullanılan parametreleri karşılaştırabilmek ve RA'lı kadın hastaların normal popülasyondan farkı olup olmadığını belirlemek için polikliniğimize değişik kas iskelet sistemi yakınmaları ile müracaat eden ve romatolojik hastalık dışındaki nedenlerle kliniğe başvuran, cinsel olarak aktif 45 kadın hastadan oluşan kontrol grubu çalışmaya dahil edildi. Hasta grubunda, cinsel partneri olmayan veya partnerinde cinsel problem olan, herhangi bir jinekolojik hastalığı olan veya jinekolojik operasyon geçirenler ve sorulara cevap vermek istemeyen toplam 25 hasta çalışma dışı bırakıldı. Toplam 100 hasta, 45 kontrol ile çalışma tamamlandı. Bu çalışma ile ilgili yerel komiteden etik kurul onayı alındı. Hastalar çalışma hakkında bilgilendirildi ve imzalı onayları alındı.

RA ve kontrol grubundaki kadınların yaşı, medeni hali, jinekolojik açıdan menstruasyonun düzenli olup olmadığı veya menopozda olup olmadıkları, eğitimleri, ekonomik bağımsızlıklarının olup olmadığı, ve RA'lı hastaların hastalık başlangıç zamanları sorgulandı. RA ve kontrol grubunun vücut ağırlığı ve boyları ölçüldü. Hastaların vücut kompozisyonu; vücut ağırlığının (kg) boy uzunluğunun $(\mathrm{m})$ karesine bölünmesi $\left(\mathrm{kg} / \mathrm{m}^{2}\right)$ formülüyle hesaplanan vücut kütle indeksi (VKi) ile değerlendirildi. Hastaların son bir haftadaki sabah tutukluğu sorgulandı ve sabah yataktan kalktıktan sonra var olan eklem tutukluğunun tamamen normale döndügü zamana kadar geçen süre dakika olarak kaydedildi. Ağrı ve yorgunluk değerlendirmesinde vizüel analog skala (VAS) kullanıldı. Üzerinde 0 (yok)'dan 100 (çok şiddetli)'e kadar numara verilen çizgi hastaya tanıtıldı. Hastadan son bir hafta içinde hissettiği ağrı ve yorgunluğa ayrı ayrı puan vermesi istendi. Hastaların RA'ya yönelik kullanmakta oldukları hastalık modifiye edici antiromatizmal ilaçlar (HMARI) ve bunların birbirleriyle kombinasyonu sorularak kaydedildi. Hastaların ekstraartiküler tutulumlarının olup olmadığı kliniğimizdeki takip dosyalarından araştırılıp kaydedildi.

Hastaların günlük yaşamdaki fonksiyonel durumunu degerlendirmek için "Sağlık Değerlendirme Anketi Hastalık İndeksi (SDA Hi)" (Health Assessment Questionnaire Disease Index; HAQ DI) kullanıldı. SDA Hi hastanın fonksiyonel yetenek seviyesini değerlendiren bir form olup, üst ekstremitenin ince motor hareketlerini, alt ekstremitenin lokomotor aktivitelerini ve hem üst hem de alt ekstremiteler ile ilgili değişik aktiviteleri içermektedir $(15,16)$. Hasta grubunda eklem tutulumunun şiddeti Ritchie Artiküler İndeks (RAI) ile değerlendirildi (17). Hastaların günlük yaşam aktiviteleri Amerikan Romatizma Birliği (American Rheumatism Association; ARA) fonksiyonel sınıflaması (ARB FS) ile (18), hastaların hastalık aktivitesi, Hastalık Aktivite Skoru-28 (HAS-28) (Disease Activity Score-DAS-28) ile değerlendirildi (19).

Şiş eklem ve hassas eklem sayısını belirlemek için vücuttaki tüm eklemler palpasyon ile değerlendirildi. Omuzlar, dirsekler, el bilekleri, dizler, ayak bilekleri ile el ve ayakların küçük eklemlerinin şişliği ve hassasiyeti kaydedildi. Sağdaki ve soldaki her 5 metakarpofalengeal (MKF), 5 proksimal interfalengeal (PIF) eklem ve 5 metatarsofalengeal (MTF) eklem ayrı eklemler olarak değerlendirildi. Kısıtlı eklem sayısını belirlemek için kısıtlı olduğu düşünülen eklemlerin hareket genişliği gonyometrik ölçüm yapılarak değerlendirildi ve normal eklem hareket genişliği ile karşılaştırıldı. Hareketi kısıtlı olarak bulunan eklemler sayısal olarak kaydedildi. Ayrıca mevcut eklem deformiteleri de sayısal olarak kaydedildi.

El kavrama kuvveti, Jamar hidrolik el dinamometresi (Preston Co., USA) ile değerlendirildi. Ölçümler; her iki elde, hasta oturur pozisyonda, omuz adduksiyonda, kol nötral pozisyonda ve ön kol $90^{\circ}$ fleksiyonda (gövdeden destek almadan) iken yapıldı. Uygun pozisyon verildikten sonra hastadan dinamometreyi 2-5 saniye 
boyunca maksimum kuvvetle sıkması istendi. Değerler kilogram cinsinden kaydedildi. Bu ölçüm üç kez tekrarlanıp ortalaması alındı.

Inflamatuvar aktiviteyi gösteren eritrosit sedimentasyon hızı (ESH) Westergren yöntemiyle, serum C-reaktif protein (CRP) nefelometrik yöntemle değerlendirildi. Romatoid faktör (RF) titreleri lateks aglutinasyon yöntemiyle değerlendirildi ve RF pozitifliği kaydedildi.

Hastaların her iki el, ayak, kalça ve diz direkt grafileri antero-posteriar pozisyonda çektirildi. Bu grafiler Larsen skorlamasına göre, her iki elde $5 \mathrm{MKF}$ ve $5 \mathrm{PiF}$, her iki ayakta 5 MTF ve 5 Pif eklemleri ve her iki kalça ve diz eklemi değerlendirmeye alındı ve tek gözlemci tarafından değerlendirildi (20). Kalça ve diz için eklem harabiyetinin radyografilere yansıyan bulguları kadranlara ayırmaksızın 0-5 arasında puanlandırıldı.

Hastaların ve kontrol grubunun tamamına seksüel disfonksiyonu değerlendirmek amacıyla Kadın Seksüel Fonksiyon İndeksi (KSFI) (Female Sexual Function Index; FSFI) sorgulama formu uygulandı. KSFi; Wiegel ve ark. (21) tarafından 2000 yılında geliştirilmiş, 19 sorudan oluşan kadın seksüel disfonksiyonunun altı ayrı boyutunu sorgulayan kendi kendine uygulanabilen bir sorgulama formudur (Tablo 1). Her bir soru için toplam puan 5 dir. KSFI sorgulamasında düşük skor düşük fonksiyonu gösterir ve toplam en yüksek skor 95'tir (skorlama aralığı 4-95).

Hasta ve kontrol grubunun tamamına Beck Depresyon Ölçeği (BDÖ) sorgulama formu uygulandı. BDÖ, depresyonda görülen vejetatif, duygusal, bilişsel, motivasyonel alanlarda ortaya çıkan belirtileri ölçmeye yarayan, 21 maddeden oluşmuş bir ölçektir. Toplam puan 0-63 arasında değişir. Depresyonda puan dağılımı şöyledir: 11-17 hafif derecede depresyon, 18-29 orta derecede depresyon, 30-63 şiddetli derecede depresyon (22).

Verilerin analizi "SPSS for Windows 11.5" paket programında yapıldı. Sürekli ölçümlü değişkenlerin dağılımının normale uygun olup olmadığı Shapiro Wilk testi ile araştırıldı. Tanımlayıcı istatistikler sürekli ölçümlü değişkenler için ortalama \pm standart sapma (minimum - maksimum) şeklinde, nominal değişkenler ise gözlem sayısı ve yüzde (\%) olarak gösterildi. Bağımsız gruplar arasında sürekli ölçümlü değişkenler yönünden istatistiksel olarak anlamlı bir farkın olup olmadığı, bağımsız grup sayısı iki olduğunda Student's t veya Mann Whitney $U$ testi ile bağımsız grup sayısının ikiden fazla olduğu durumlarda ise Kruskal Wallis testi ile değerlendirildi. Kruskal Wallis test istatistiği sonucunun önemli bulunduğu durumlarda anlamlı farka neden olan grup veya grupları tespit etmek amacıyla çoklu karşılaştırma testleri kullanıldı.

Tablo 1. Kadın seksüel fonksiyon indeksi skorlaması.

\begin{tabular}{|l|l|l|l|l|}
\hline Madde & Soru numarası & Skor aralığı & Min. skor & Maks. skor \\
\hline Arzu & 1,2 & $1-5$ & 2 & 10 \\
\hline Uyarıma & $3,4,5,6$ & $0-5$ & 0 & 20 \\
\hline Lubrikasyon & $7,8,9,10$ & $0-5$ & 0 & 20 \\
\hline Orgazm & $11,12,13$ & $0-5$ & 0 & 15 \\
\hline Tatmin & $14,15,16$ & 0 (veya 1$)-5$ & 2 & 15 \\
\hline Ağrı & $17,18,19$ & $0-5$ & 0 & 15 \\
\hline Toplam & & & 4 & 95 \\
\hline
\end{tabular}

(14. soru için $0-5 ; 15$. ve 16 . soru için $1-5$ arası skorlama yapııır).
Nominal değişkenler Pearson'un Ki-Kare veya Fisher'in Tam Sonuçlu Olasılık testi ile değerlendirildi. Sürekli değiş̧keler arasındaki doğrusal ilişkinin büyüklüğü Spearman'ın "rho" katsayısı ve önemlilik düzeyi hesaplanarak incelendi. Tek değişkenli korelasyon testleri sonucunda KSFI alt boyut ve KSFI toplam puanları üzerinde etkili olan veya etkili olabileceği düşünülen risk faktörlerinin birlikte etkilerini incelemek amacıyla Çoklu Doğrusal Regresyon analizi kullanıldı. Regresyon analizi sonucunda herbir bağımsız değişkene ilişkin regresyon katsayısı, \%95 güven aralığı ve önemlilik düzeyleri saptandı. KSFI alt boyut ve KSFI toplam puanları ölçümleri normal dağılmadığı için Doğrusal Regresyon analizlerinde logaritmik dönüşüm değerleri kullanıldı. $p<0,05$ için sonuçlar istatistiksel olarak anlamlı kabul edildi.

\section{Bulgular}

Çalışmaya alınan 100 kadın RA hastasının yaşları 21 ile 60 yıl

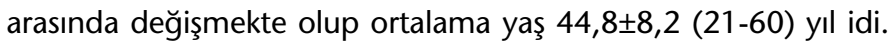
45 kadın kontrol bireyinin yaş ortalaması ise $44,7 \pm 8,5$ (26-59) yıl idi. İki grubun yaş ortalamaları arasında istatistiksel olarak anlamlı fark yoktu ( $p>0,05)$. Çalışmaya dahil edilen iki grubun öğrenim düzeyi ve VKi arasında istatistiksel olarak anlamlı fark yoktu $(p>0,05)$. Bununla birlikte kontrol grubunda ekonomik bağımsızlık oranı RA grubuna oranla istatistiksel olarak anlamlı derecede yüksekti $(p<0,001)$. Jinekolojik durum açısından iki grup arasında istatistiksel olarak anlamlı fark yoktu $(p>0,05)$. RA ve kontrol grubunun demografik verileri Tablo 2 'de verilmiştir.

RA'lı hastaların kadın seksüel fonksiyon indeksi alt ölçek ve toplam skorlarının hepsi kontrol grubundaki hastalara göre istatistiksel olarak anlamlı derecede düşük saptandı. RA'lı hastaların BDÖ skorları kontrol grubuna göre istatistiksel olarak anlamlı derecede yüksekti $(p=0,004)$. RA ve kontrol grubunun

Tablo 2. Demografik veriler.

\begin{tabular}{|l|l|l|l|}
\hline & Kontrol $(\mathbf{n}=45)$ & RA (n=100) & $\mathbf{p}$ \\
\hline Yaş (yıl) & $44,7 \pm 8,5$ & $44,8 \pm 8,2$ & $0,957^{\mathrm{a}}$ \\
\hline Öğrenim düzeyi & - & - & $0,175^{\mathrm{b}}$ \\
\hline Okur yazar değil & $12(\% 26,7)$ & $29(\% 29)$ & - \\
\hline Okur yazar & $3(\% 6,7)$ & $4(\% 4)$ & - \\
\hline Illkokul & $13(\% 28,9)$ & $46(\% 46)$ & - \\
\hline Ortaokul & $11(\% 24,4)$ & $17(\% 17)$ & - \\
\hline Lise & $3(\% 6,7)$ & $4(\% 4)$ & - \\
\hline Üniversite & $3(\% 6,7)$ & - & - \\
\hline Vücut kütle indeksi $\left(\mathrm{kg} / \mathrm{m}^{2}\right)$ & $28,0 \pm 3,1$ & $27,7 \pm 3,6$ & $0,535^{\mathrm{a}}$ \\
\hline Ekonomik bağımsızlık & - & - & $<0,001^{\mathrm{b}}$ \\
\hline Yok & $34(\% 75,6)$ & $94(\% 94)$ & - \\
\hline Var & $11(\% 24,4)$ & $6(\% 6)$ & - \\
\hline linekolojik durum & & & \\
\hline Düzenli & $24(\% 53,3)$ & $38(\% 38)$ & - \\
\hline Düzensiz & $5(\% 11,1)$ & $18(\% 18)$ & $0,205^{\mathrm{b}}$ \\
\hline Postmenopozal & $16(\% 35,6)$ & $44(\% 44)$ & \\
\hline
\end{tabular}

aStudent's t testi.

$b_{\text {Pearson Ki-Kare testi. }}$ 
Tablo 3. Kadın seksüel fonksiyon indeksi alt ölçek ve toplam skorların ve Beck depresyon ölçeği puanının gruplar arasında dağılımı.

\begin{tabular}{|l|l|l|l|}
\hline & Kontrol & RA & p $^{\mathbf{a}}$ \\
\hline Arzu & $5,8 \pm 2,02$ & $4,5 \pm 2,13$ & $<0,001$ \\
\hline Uyarılma & $13,2 \pm 3,73$ & $9,3 \pm 4,32$ & $<0,001$ \\
\hline Lubrikasyon & $15,2 \pm 3,30$ & $11,8 \pm 4,97$ & $<0,001$ \\
\hline Orgazm & $8,2 \pm 2,80$ & $6,8 \pm 3,75$ & 0,015 \\
\hline Tatmin & $10,5 \pm 2,61$ & $8,5 \pm 3,74$ & 0,003 \\
\hline Ağrı & $13,6 \pm 1,47$ & $9,8 \pm 3,77$ & $<0,001$ \\
\hline Toplam & $66,6 \pm 12,38$ & $50,7 \pm 17,91$ & $<0,001$ \\
\hline BDÖ & $13,7 \pm 7,45$ & $18,8 \pm 9,82$ & 0,004 \\
\hline
\end{tabular}

BDÖ: Beck Depresyon Ölçeği

${ }^{\mathrm{a}}$ Mann Whitney $\mathrm{U}$ testi.

Tablo 4. Romatoid artritli hastalara ait klinik ve radyolojik değerlendirme sonuçları.

\begin{tabular}{|c|c|}
\hline & Tanımlayıcı Istatistiklera \\
\hline Deformite sayısı $^{a}$ & $2,4 \pm 3,7(0-16)$ \\
\hline Şiş eklem sayısı ${ }^{a}$ & $2,3 \pm 4,2(0-26)$ \\
\hline Hassas eklem sayısı $^{a}$ & $13,8 \pm 7,8(0-28)$ \\
\hline Kısıtlı eklem sayısı ${ }^{a}$ & $2,9 \pm 4,2(0-21)$ \\
\hline $\mathrm{RA}^{\mathrm{a}}$ & $18,3 \pm 11,4(0-50)$ \\
\hline Kavrama gücü (kg) sağ & $8,6 \pm 6,0(0-24)$ \\
\hline Kavrama gücü $(\mathrm{kg})$ sol & $8,5 \pm 5,6(0-22)$ \\
\hline ARB FS ${ }^{\mathrm{a}}$ & $2,1 \pm 0,9(0-4)$ \\
\hline HAS- $28^{a}$ & $5,2 \pm 1,3(1,7-7,8)$ \\
\hline RF pozitifliğib & $69(\% 69,0)$ \\
\hline Hastalık süresi (yll) & $7,9 \pm 7,3(0,5-30)$ \\
\hline Sabah tututluluk süresi (dakika) & $37,7 \pm 41,0(0-140)$ \\
\hline HMARI sayıII & $1 \pm 0,6(0-3)$ \\
\hline VAS ağrı & $52,0 \pm 22,6(10-90)$ \\
\hline VAS yorgunluk & $58,9 \pm 23,3(10-90)$ \\
\hline SDA HI & $1,4 \pm 0,9(0-5)$ \\
\hline \multicolumn{2}{|l|}{ Larsen radyolojik skorları } \\
\hline Sağ el & $21,1 \pm 10,6(2-47)$ \\
\hline Sol el & $20,9 \pm 10,1(1-44)$ \\
\hline Sağ ayak & $16,8 \pm 8,4(3-42)$ \\
\hline Sol ayak & $16,4 \pm 9,1(2-45)$ \\
\hline Sağ kalça & $1,4 \pm 1,4(0-5)$ \\
\hline Sol kalça & $1,1 \pm 1,3(0-4)$ \\
\hline Sağ diz & $1,1 \pm 1,2(0-5)$ \\
\hline Sol diz & $1,1 \pm 1,2(0-4)$ \\
\hline Toplam & $75,2 \pm 35,6(16-176)$ \\
\hline
\end{tabular}

RAI: Ritchie Artiküler Indeks, HAS-28: Hastalık Aktivite Skoru-28,

ARB FS: Amerikan Romatizma Birliği Fonksiyonel Sinfflama, RF: Romatoid Faktör, HMARI: Hastalik Modifiye Edici Antiromatizmal llaç, SDA HI: Sağlık Değerlendirme Anketi Hastallk Indeksi, VAS: Vizüel Analog Skala

${ }^{a}$ Veriler Ortalama \pm Standart Sapma (Minimum - Maksimum) olarak gösterildi.

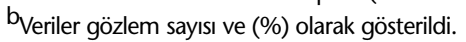

KSFI ve BDÖ skorlarının gruplar arasındaki dağılımı tablo $3^{\prime}$ de verilmişitir. RA'ı hastalara ait klinik ve radyolojik değerlendirme sonuçları tablo $4^{\prime}$ te verilmiştir.

Ekstraartiküler bulgular açııından değerlendirildiğinde RA'ı hastaların 13 (\%13)'ünde akciğer tutulumu, 9 (\%9)'unda Sjögren sendromu, 12 (\%12)'sinde göz tutulumu ve 20 (\%20)'sinde subkutan nodül mevcuttu. RA grubunda ortalama CRP düzeyi $1 \pm 1,15 \mathrm{mg} / \mathrm{dl}$, ESH düzeyi $29,2 \pm 17,1 \mathrm{~mm} /$ saat olarak saptandı. Kontrol grubunda ise CRP düzeyi $0,5 \pm 0,30 \mathrm{mg} / \mathrm{dl}$, ESH düzeyi $9,8 \pm 4,62 \mathrm{~mm} / \mathrm{saat}$ olarak saptandı. RA'lı hastalarda CRP ve ESH düzeyleri kontrol grubuna göre istatistiksel olarak anlamlı derecede yüksekti.

RA grubunda menstruasyonu düzenli olan hastalarda ağrı dışındaki KSFi alt birim ve toplam skorları en yüksek, menstruasyonu düzensiz kadınlarda daha düşük KSFi skorları ve postmenopozal kadınlarda en düşük KSFI skorları saptanmıştır. Bu fark istatistiksel olarak anlamlıydı. Jinekolojik durumun KSFI'ye etkisi Tablo $5^{\prime}$ de gösterilmiştir.

RA grubu içerisinde ekonomik bağımsızlığı olan kadınlarda KSFI'nin orgazm, ağıı alt parametreleri ve toplam skoru ekonomik bağımsızlığı olmayan kadınlara göre istatistiksel olarak anlamlı olarak yüksekti $(p<0,05)$. RA grubunda ekonomik bağımsızlık durumunun KSFi'ye etkisi Tablo 6'da gösterilmiştir.

RA'da hastalık değişkenleri ile KSFI arasındaki ilişki Tablo 7'de belirtilmiştir. RA'Iı hastalarda; yaş artıkça KSFI'nin ağrı dışındaki tüm alt paremetreleri ve toplam skoru, VKI artıkça arzu ve tatmin dışındaki tüm alt paremetre ve toplam skoru, hastalık süresi arttıkça lubrikasyon ve tatmin dışındaki tüm alt parametreleri ve toplam skoru, sabah tutukluğu süresi arttıkça lubrikasyon ve orgazm dışında tüm alt parametreleri ve toplam skoru istatistiksel olarak anlamlı derecede azalıyordu. Hastaların eğitim düzeyi arttıkça KSFI'nin tatmin ve ağrı dışındaki tüm alt parametre skorları ve toplam skoru istatistiksel olarak belirgin artıyordu. Hastaların VAS yorgunluk düzeyi arttıkça KSFI'nin lubrikasyon dışındaki tüm alt parametre ve toplam skoru istatistiksel olarak belirgin azalıyordu. RA'lı hastalarda VAS ağrı düzeyi, SDA HI düzeyi, BDÖ skorları arttıkça KSFI'nin tüm alt birim skorları ve toplam skor istatistiksel açıdan anlamlı derecede azalıyordu.

RA'da klinik değişkenlerin KSFl'ye olan etkisi Tablo 8'de verilmiştir. RA hastalarında deformite sayısı, RAl skoru ve ARB fonksiyonel düzey arttıkça KSFI alt ölçek skorlarının hepsi ve toplam skor, sağ ve sol el kavrama gücü azaldıkça alt ölçek skorlarının hepsi ve toplam skor istatistiksel olarak anlamlı şekilde azalıyordu. Şiş eklem sayısı arttıkça KSFI'nin uyarılma, orgazm, tatmin ve toplam skoru, hassas eklem sayısı arttıkça arzu, lubrikasyon, orgazm, tatmin, ağrı ve toplam skoru istatistiksel olarak anlamlı şekilde azalıyordu. Kısıtı eklem sayısı ve HAS-28 düzeyi arttıkça KSFI'nin lubrikasyon dışındaki tüm alt ölçekleri ve toplam skoru istatistiksel olarak anlamlı azalıyordu.

RA grubunda CRP düzeyi artıkça KSFI'nin tatmin alt birimi ve toplam skoru, ESH artıkça KSFI'nin tüm alt birimleri ve toplam skoru istatistiksel olarak anlamlı azalıyordu. Bu bulgular Tablo 9'da gösterilmiştir. RA grubu içerisinde RF pozitifliğinin KSFI alt parametreleri ve toplam skoruna istatistiksel olarak anlamlı derecede etkisi gözlenmedi $(p>0,05)$. 
RA grubunda yapılan Larsen radyolojik değerlendirmede, sağ el skoru arttıkça KSFI'nin tatmin dışındaki tüm alt parametreleri ve toplam skoru, sol el skoru arttıkça KSFI'nin lubrikasyon dışındaki tüm alt parametreleri ve toplam skoru istatistiksel olarak anlamlı derecede azalıyordu. Sağ ve sol ayak, sağ ve sol kalça ve toplam radyolojik skor arttıkça KSFI'nin tüm alt parametreleri ve toplam skoru istatistiksel olarak anlamlı derecede azalıyordu. Sağ dizde radyolojik skor arttıkça KSFi'nin lubrikasyon ve ağrı alt birim ve toplam skor, sol dizde radyolojik skor arttıkça KSFi'nin arzu, lubrikasyon, orgazm alt birimleri ve toplam skorda istatistiksel olarak anlamlı derecede azalış gözlendi. RA grubu içerisinde Larsen skorlamasının KSFi'ye olan etkisi Tablo 10'da gösterilmiştir.

RA hastaları sistemik tutulum açısından değerlendirildiğinde; akciğer tutulumu olan RA hastalarında KSFI'nin arzu, uyarıma, ağrı alt birimleri ile toplam skoru istatistiksel olarak anlamlı derecede azalmış bulundu $(p<0,05)$. Sjögren sendromu bulunan hastaların sadece lubrikasyon alt birim skorunda istatistiksel olarak anlamlı azalma tespit edilmiştir $(p<0,05)$. RA hastalarında subkutan nodül varlığında KSFI'nin orgazm alt birimi skoru dışında hiçbir skorda istatistiksel olarak anlamlı azalma gözlenmemiştir $(p>0,05)$. RA hastalarında HMARI kullanımının veya kullanılan HMARI sayısının KSFI'nin alt parametrelerine ve toplam skora istatistiksel olarak anlamlı bir etkisi gözlenmedi ( $p>0,05)$.

Çoklu doğrusal regresyon analizine göre diğer risk faktörlerinin etkisi sabit bırakıldığında; arzu alt boyutundaki

Tablo 5. Romatoid artrit grubunda jinekolojik durumun kadın seksüel fonksiyon indeksine olan etkisi.

\begin{tabular}{|l|l|l|l|l|}
\hline & Düzenli & Düzensiz & Postmenopozal & $\mathrm{p}^{\mathbf{a}}$ \\
\hline Arzu & $5,2 \pm 2,4$ & $4,6 \pm 2,1$ & $3,8 \pm 1,7 \mathrm{~b}$ & 0,008 \\
\hline Uyarılma & $10,4 \pm 4,1$ & $10,6 \pm 4,7$ & $7,9 \pm 4,1 \mathrm{c}, \mathrm{d}$ & 0,015 \\
\hline Lubrikasyon & $13,6 \pm 4,2$ & $12,5 \pm 4,4$ & $10,0 \pm 5,2^{\mathrm{b}}$ & 0,006 \\
\hline Orgazm & $8,3 \pm 3,9$ & $7,4 \pm 3,1$ & $5,3 \pm 3,3 \mathrm{~b}, \mathrm{~d}$ & $<0,001$ \\
\hline Tatmin & $10,0 \pm 3,6$ & $8,2 \pm 4,2$ & $7,3 \pm 3,2^{\mathrm{b}}$ & 0,004 \\
\hline Ağrı & $10,5 \pm 3,7$ & $9,8 \pm 3,7$ & $9,2 \pm 3,8$ & 0,247 \\
\hline Toplam & $58,0 \pm 16,7$ & $53,0 \pm 18,4$ & $43,5 \pm 16,2 \mathrm{~b}, \mathrm{~d}$ & 0,002 \\
\hline
\end{tabular}

${ }^{a}$ Kruskal Wallis testi.

${ }^{b}$ Düzenli grup ile arasındaki fark istatistiksel olarak anlamlı $(p<0,001)$.

${ }^{C}$ Düzenli grup ile arasındaki fark istatistiksel olarak anlamlı $(p<0,01)$.

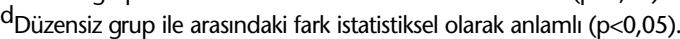

Tablo 6. Romatoid artrit grubunda ekonomik bağımsızlık durumunun kadın seksüel fonksiyon indeksine etkisi.

\begin{tabular}{|l|l|l|l|}
\hline & Çalışmayan & Çalışan & $p^{\mathbf{a}}$ \\
\hline Arzu & $4,4 \pm 2,1$ & $5,2 \pm 1,7$ & 0,223 \\
\hline Uyarılma & $9,2 \pm 4,4$ & $11,3 \pm 2,6$ & 0,143 \\
\hline Lubrikasyon & $11,6 \pm 5,0$ & $15,2 \pm 2,5$ & 0,088 \\
\hline Orgazm & $6,6 \pm 3,7$ & $9,8 \pm 2,8$ & 0,031 \\
\hline Tatmin & $8,3 \pm 3,7$ & $11,3 \pm 2,9$ & 0,051 \\
\hline Ağrı & $9,5 \pm 3,7$ & $14,2 \pm 1,7$ & $<0,001$ \\
\hline Toplam & $49,7 \pm 17,9$ & $67,0 \pm 8,0$ & 0,019 \\
\hline
\end{tabular}

${ }^{\mathrm{a}}$ Mann Whitney U testi. puanların azalması üzerinde hastalık süresi, SDA Hï, BDÖ ve ARB FS'nin, uyarılma alt boyutundaki puanların azalması üzerinde $B D O ̈$ ve $A R B$ FS'nin, lubrikasyon alt parametresindeki puanların azalması üzerinde BDÖ'nün, orgazm alt parametresindeki puanların azalması üzerinde yaşın ilerlemesi ve BDÖ’nün, tatmin alt parametresindeki puanların azalması üzerinde BDÖ’nün istatistiksel olarak anlamlı etkileri devam etmekte idi. Ağrı alt parametresindeki puanların azalması üzerinde hiç bir risk faktörünün istatistiksel olarak anlamlı etkiye sahip olmadığı gözlendi. Çoklu doğrusal regresyon analizine göre diğer risk faktörlerinin etkisi sabit bırakıldığında KSFi toplam puanlarının azalması üzerinde de sadece BDÖ'nün büyümesinin istatistiksel olarak anlamlı etkileri devam etmekte idi. RA grubunda KSFI alt skor ve toplam puanı üzerinde etkili olabileceği düşünülen risk faktörlerinin çoklu etkileri Tablo 11 'de gösterilmiştir.

\section{Tartışma}

Bir çok hastalık insanlarda seksüel aktiviteyi etkileyebilmektedir (23). Özellikle RA gibi kronik, sistemik ve inflamatuvar durum yaratan ve aynı zamanda ağrının yoğun olduğu ve potansiyel fiziksel dizabilite nedeni olan hastalıklarda seksüel aktivite sıkıkla etkilenir. RA, yaşamın her parçasında olduğu gibi eşler arasındaki ilişki ve seksüel fonksiyonlar üzerinde de belirgin değişikliklere neden olur. RA, tüm yönleriyle ayrıntılı incelenmiş bir hastalık olsa da seksüalite hala çok az tartışılan bir alan olmaya devam etmektedir $(24,25)$. Bu durum hastalar için ciddi bir handikaptır. Çünkü seksüel yaşam bir çok insan için yaşamın önemli bir parçasını oluşturmaktadır. Her insan seksüeldir. Seksüalite bir bireyin kendisini dişilik veya erkeklik şeklinde gösteren kişiliğinin, fiziksel, emosyonel, entellektüel ve sosyal yanlarını bütünleşmesidir; yani bu temelde bir kişinin duygularını, sevgisini bir başkasına ifade etme, iletebilme şeklidir. Insan seksüalitesi bireyin emosyonel ve kognitif fonksiyonuna dayanır. Freud 1936 'da seksüaliteyi; genital organ fonksiyonundan ziyade insani bir eylem biçimi olarak tanımlamış ve beyinin temel seks organı olduğu vurgulamıştır (26).

Seksüel deneyim, kişiliğin oluşmasının ve bireyin temel özelliklerinin bir parçasıdır ve sağlığın ve hastalığın tüm basamaklarında önemli bir rol oynamaktadır (27). Kronik böbrek yetmezliği ve diyabetes mellitus gibi diğer kronik hastalıklarla karşılaştırıldığında, RA'da kadın seksüel fonksiyonunu araştıran az sayıda çalışma vardır. RA, normal popülasyonda \%1 civarında görülür ve kadınlarda daha sıktır. Seksüel aktifliğin en yoğun olduğu 3-5. dekatlar RA'nın en sık başlangıç gösterdiği dekatlardır (28). Bu nedenle RA'lı kadın hastalarda seksüel disfonksiyon daha fazla araştırıması gereken bir konudur. Biz bu çalısmada, RA'ı kadın hastalardaki seksüel disfonksiyonun varlığını ve RA hastalığının alt parametreleriyle arasındaki ilişkiyi; normal popülasyondaki kadınlarla arasındaki farklııkları ya da benzerlikleri geçerli bir anket yöntemi olan kadın seksüel fonksiyon indeksi kullanarak araştırdık.

RA grubunda, KSFI'nin alt birimleri olan arzu, uyarılma, lubrikasyon, orgazm, tatmin ve ağrı skorlarılla toplam KSFi skoru kontrol grubuna göre anlamlı olarak düşük bulundu. Yoshino ve Uchida (8) yaptıkları çalışmada, RA'ı kadın hastaların kontrol 
grubu ile karşılaştırıldığında; seksüel ilişki sayııında ve orgazm sıklığında azalma saptamışlardır. RA'lı kadın hastaların $\% 50$ 'sinden fazlasında seksüel arzu düzeyinde ve $\% 60$ 'ından fazlasında seksüel tatmin düzeyinde azalma olduğunu rapor etmişlerdir. Bhadauria ve ark. (29), RA'ı kadın hastalarda seksüel problemlerin varlığını rapor etmişler ve bunun nedenini azalmış arzu (\%53) ve azalmış cinsel ilişki sıklığı (\%40) olarak göstermişlerdir. Elst ve ark. (12), sağlıklı toplumla karşılaştıııldığında RA'ı hastaların daha yüksek oranda seksüel tiksinti bozukluğuna sahip olduklarını göstermişlerdir. Blake ve ark. (30) da sağlıklı popülasyona göre hem seksüel tatmin bozukluğunun hem de seksüel dizabilitenin RA'ı kadın hastalarda çok daha yaygın olduğunu göstermişlerdir. Ağrı, yorgunluk, sabah tutukluğu, dizabilite, kalça ve diz tutulumu gibi hastalıkla ilişkili parametreler ve depresyon, değişmiş vücut imajı ve partnerin azalmış ilgisinden endişe etme gibi psikolojik değişkenlerin RA'daki seksüel disfonksiyonun muhtemel nedenleri olabileceği çeşitli çalışmalarda vurgulanmıştır $(13,29-31)$. Bizim bulgularımız da literatürdeki bu bilgilerle uyumluydu.

RA grubu KSFI alt parametreleri ve toplam skoru ile yaş arasındaki ilişki açısından kendi içinde incelendiğinde, yaşın ağrı dışındaki tüm alt parametrelere ve toplam skora anlamlı derecede negatif etkisi olduğu gözlenmiştir. Öte yandan eğitim düzeyi arttıkça KSFI'nin tatmin ve ağrı dışındaki alt parametreleri ve toplam skoru belirgin olarak artıyordu. Bu bulguları destekler şekilde van Berlo ve ark. (32), RA'ı yaşı kadınlarda daha düşük seksüel aktivite saptamışlar ve bunun nedeni olarak ta ileri yaşla birlikte ek hastalıklar gibi daha öncelikli problemlerin baş gösterebileceğini bildirmişlerdir. Yine aynı çalışmada, eğitim düzeyi artıkça seksüel disfonksiyon oranlarının azaldığı vurgulanmıştır. Kinsey ve ark. (33) ise yaşlanmayı seksüel aktivitedeki azalmanın en önemli nedeni olarak göstermişlerdir. Bizim bulgularımız da literatürle uyumluydu. Regresyon analizleri de yaşın ilerlemesiyle seksüel disfonksiyonun özellikle orgazm alt parametresinde belirgin azalma olduğunu göstermiştir.

Çalışma grubumuzdaki RA'lı kadın hastalardan ekonomik bağımsızlı̆ga sahip olanlarda, olmayanlara göre KSFi'nin orgazm, ağıı alt parametreleri ve toplam skoru istatistiksel olarak anlamlı olarak yüksek tespit edildi. Buna göre çalışma hayatının ve ekonomik bağımsızlı̆ın hastanın sosyal izolasyonunu engellediği, kendine güvenini artırdığı bu durumun da seksüel yaşama olumlu yönde katkıda bulunduğu görülmektedir. Kadın cinsel fonksiyon bozukluğu ile ilgili en geniş seriye sahip çalışmalardan biri olan 'Amerika Ulusal Sağlık ve Sosyal Yaşam Araştırması' verilerinin derlendiği çalışmada kadının eğitim düzeyi arttıkça ve ekonomik bağımsızlık geliştikçe cinsel sorunların daha az yaşandığı bildirilmiştir (34).

Tablo 7. Romatoid artritte hastalık değişkenleri ile kadın seksüel fonksiyon indeksi arasındaki ilişki.

\begin{tabular}{|c|c|c|c|c|c|c|c|c|}
\hline & & Arzu & Uyarılma & Lubrikasyon & Orgazm & Tatmin & Ağrı & Toplam \\
\hline \multirow{2}{*}{ Yaş (yıl) } & rho & $-0,377$ & $-0,335$ & $-0,318$ & $-0 ., 89$ & $-0,297$ & $-0,140$ & $-0,372$ \\
\hline & $p$ & $<0,001$ & $<0,001$ & $<0,001$ & $<0,001$ & 0,003 & 0,166 & $<0,001$ \\
\hline \multirow[t]{2}{*}{ VKI $\left(\mathrm{kg} / \mathrm{m}^{2}\right)$} & rho & $-0,178$ & $-0,260$ & $-0,232$ & $-0,226$ & $-0,196$ & $-0,244$ & $-0,290$ \\
\hline & $p$ & 0,076 & 0,009 & 0,020 & 0,024 & 0,051 & 0,014 & 0,003 \\
\hline \multirow[t]{2}{*}{ Eğitim } & rho & 0,251 & 0,269 & 0,216 & 0,312 & 0,139 & 0,134 & 0,271 \\
\hline & $\mathrm{p}$ & 0,012 & 0,007 & 0,031 & 0,002 & 0,169 & 0,185 & 0,006 \\
\hline \multirow[t]{2}{*}{ Hastalık süresi } & rho & $-0,311$ & $-0,342$ & $-0,132$ & $-0,226$ & $-0,186$ & $-0,292$ & $-0,302$ \\
\hline & $p$ & 0,002 & $<0,001$ & 0,191 & 0,023 & 0,065 & 0,003 & 0,002 \\
\hline \multirow{2}{*}{$\begin{array}{l}\text { Sabah tutukluğu } \\
\text { süresi (dak.) }\end{array}$} & rho & $-0,258$ & $-0,284$ & $-0,155$ & $-0,167$ & $-0,249$ & $-0,243$ & $-0,288$ \\
\hline & $p$ & 0,010 & 0,004 & 0,124 & 0,097 & 0,013 & 0,015 & 0,004 \\
\hline \multirow[t]{2}{*}{ VAS ağrı } & rho & $-0,242$ & $-0,262$ & $-0,209$ & $-0,253$ & $-0,341$ & $-0,335$ & $-0,351$ \\
\hline & $p$ & 0,015 & 0,008 & 0,037 & 0,011 & $<0,001$ & $<0,001$ & $<0,001$ \\
\hline \multirow{2}{*}{$\begin{array}{l}\text { VAS } \\
\text { yorgunluk }\end{array}$} & rho & $-0,244$ & $-0,248$ & $-0,181$ & $-0,279$ & $-0,395$ & $-0,265$ & $-0,352$ \\
\hline & $p$ & 0,014 & 0,013 & 0,071 & 0,005 & $<0,001$ & 0,008 & $<0,001$ \\
\hline \multirow[t]{2}{*}{ SDA HI } & rho & $-0,262$ & $-0,302$ & $-0,343$ & $-0,366$ & $-0,389$ & $-0,383$ & $-0,456$ \\
\hline & $p$ & 0,008 & 0,002 & $<0,001$ & $<0,001$ & $<0,001$ & $<0,001$ & $<0,001$ \\
\hline \multirow[t]{2}{*}{ BDÖ } & rho & $-0,648$ & $-0,544$ & $-0,354$ & $-0,527$ & $-0,612$ & $-0,415$ & $-0,639$ \\
\hline & $p$ & $<0,001$ & $<0,001$ & $<0,001$ & $<0,001$ & $<0,001$ & $<0,001$ & $<0,001$ \\
\hline
\end{tabular}

VKi: Vücut Kütle İndeksi, BDÖ: Beck Depresyon Ölçeği, SDA Hi: Sağlık Değerlendirme Anketi Hastalık Indeksi, VAS: Vizüel Analog Skala. 
Bizim çalışmamızda hastalık süresinin uzun olması KSFI'nin lubrikasyon ve tatmin dışında tüm alt birimlerini ve toplam skorunu anlamlı dercede olumsuz yönde etkilemekteydi. Bu bizim bekleyebileceğimiz bir sonuçtu. Çünkü hastalık süresi uzadıkça hastanın genellikle fonksiyonel kaybı artmakta, vücut imajı bozulmakta, kronik ağrıya bağlı depresyon veya depresif semptomlar gibi problemler ortaya çıkabilmektedir. Bunların hepsi de seksüel disfonksiyona katkıda bulunabilecek etkenlerdir. Yaptığımız regresyon analizleri hastalık süresinin seksüel disfonksiyonun özellikle arzu alt parametresini belirgin olarak olumsuz yönde etkilediğini göstermiştir.

Çalışmamızda RA'lı kadın hastaların sabah tutukluğu süresi, VAS ile belirlenmiş ağrı ve yorgunluk düzeyi arttıkça KSFI'nin tüm alt birimleri ve toplam skorunun anlamlı derecede olumsuz yönde etkilendiğini tespit ettik. Aktif inflamasyonun göstergeleri olan artmış sabah tutukluğu, ağrı ve yorgunluğun seksüel disfonksiyona yol açabilmesi beklenen bir durumdur. Daha önceki çalışmalarda RA'lı hastalarda ağrı, sabah tutukluğu ve yorgunluğun seksüel problemlere neden olduğu gösterilmiştir $(8,12,29,35)$. Yine RA hastalarındaki semptomların seksüel yaşam üzerine etkilerini inceleyen başka çalışmalarda ağrı, yorgunluk ve fiziksel fonksiyon kaybının seksüel memnuniyeti etkilediği bildirilmiştir (12,14,30). Ayrıca, Gutweniger ve ark. (10), sabah tutukluğunun kadın RA hastalarında kendini iyi hissetme yönünden önemli rol oynadığını belirtmișlerdir. Yüksek dereceli sabah tutukluğu olan kadın RA hastalarında, düşük dereceli sabah

Tablo 8. Romatoid artritte klinik değişkenlerin kadın seksüel fonksiyon indeksine olan etkisi.

\begin{tabular}{|c|c|c|c|c|c|c|c|c|}
\hline & & Arzu & Uyarıma & Lubrikasyon & Orgazm & Tatmin & Ağrı & Toplam \\
\hline \multirow{2}{*}{$\begin{array}{l}\text { Deformite } \\
\text { sayısı }\end{array}$} & rho & $-0,329$ & $-0,305$ & $-0,202$ & $-0,346$ & $-0,201$ & $-0,267$ & $-0,348$ \\
\hline & $\mathrm{p}$ & $<0,001$ & 0,002 & 0,044 & $<0,001$ & 0,045 & 0,007 & $<0,001$ \\
\hline \multirow[t]{2}{*}{ Şiş eklem sayısı } & rho & $-0,180$ & $-0,233$ & $-0,105$ & $-0,220$ & $-0,264$ & $-0,173$ & $-0,259$ \\
\hline & $\mathrm{p}$ & 0,073 & 0,019 & 0,297 & 0,028 & 0,008 & 0,086 & 0,009 \\
\hline \multirow{2}{*}{$\begin{array}{l}\text { Hassas eklem } \\
\text { sayısı }\end{array}$} & rho & $-0,199$ & $-0,181$ & $-0,229$ & $-0,281$ & $-0,367$ & $-0,305$ & $-0,351$ \\
\hline & $\mathrm{p}$ & 0,047 & 0,071 & 0,022 & 0,005 & $<0,001$ & 0,002 & $<0,001$ \\
\hline \multirow{2}{*}{$\begin{array}{l}\text { Kısıtlı eklem } \\
\text { sayısı }\end{array}$} & rho & $-0,265$ & $-0,251$ & $-0,157$ & $-0,254$ & $-0,161$ & $-0,253$ & $-0,266$ \\
\hline & $\mathrm{p}$ & 0,008 & 0,012 & 0,119 & 0,011 & 0,108 & 0,011 & 0,007 \\
\hline \multirow[t]{2}{*}{ RAi } & rho & $-0,311$ & $-0,314$ & $-0,265$ & $-0,391$ & $-0,433$ & $-0,389$ & $-0,458$ \\
\hline & $\mathrm{p}$ & 0,002 & $<0,001$ & 0,008 & $<0,001$ & $<0,001$ & $<0,001$ & $<0,001$ \\
\hline \multirow{2}{*}{$\begin{array}{l}\text { Sağ el kavrama } \\
\text { gücü }(\mathrm{kg})\end{array}$} & rho & 0,250 & 0,360 & 0,275 & 0,329 & 0,301 & 0,324 & 0,400 \\
\hline & $\mathrm{p}$ & 0,012 & $<0,001$ & 0,006 & $<0,001$ & 0,002 & $<0,001$ & $<0,001$ \\
\hline \multirow{2}{*}{$\begin{array}{l}\text { Sol el kavrama } \\
\text { gücü }(\mathrm{kg})\end{array}$} & rho & 0,322 & 0,399 & 0,314 & 0,378 & 0,309 & 0,316 & 0,438 \\
\hline & $\mathrm{p}$ & $<0,001$ & $<0,001$ & $<0,001$ & $<0,001$ & 0,002 & $<0,001$ & $<0,001$ \\
\hline \multirow[t]{2}{*}{ ARB FS } & rho & $-0,475$ & $-0,457$ & $-0,346$ & $-0,489$ & $-0,418$ & $-0,419$ & $-0,543$ \\
\hline & $\mathrm{p}$ & $<0,001$ & $<0,001$ & $<0,001$ & $<0,001$ & $<0,001$ & $<0,001$ & $<0,001$ \\
\hline \multirow[t]{2}{*}{ HAS-28 } & rho & $-0,223$ & $-0,208$ & $-0,196$ & $-0,325$ & $-0,385$ & $-0,326$ & $-0,365$ \\
\hline & $p$ & 0,026 & 0,038 & 0,051 & $<0,001$ & $<0,001$ & $<0,001$ & $<0,001$ \\
\hline
\end{tabular}

RAI: Ritchie Artiküler İndeks, ARB FS: Amerikan Romatizma Birliği Fonksiyonel Sınıfı, HAS-28: Hastalık Aktivite Skoru-28.

Tablo 9. Romatoid artrit grubu içerisinde CRP ve ESH düzeyinin kadın seksüel fonksiyon indeksine olan etkisi.

\begin{tabular}{|l|l|l|l|l|l|l|l|c|}
\hline & & Arzu & Uyarıma & Lubrikasyon & Orgazm & Tatmin & Ağrı & Toplam \\
\hline \multirow{2}{*}{ CRP (mg/dl) } & rho & $-0,079$ & $-0,129$ & $-0,124$ & $-0,144$ & $-0,175$ & $-0,120$ & $-0,182$ \\
\cline { 2 - 10 } & $\mathrm{p}$ & 0,348 & 0,122 & 0,137 & 0,085 & 0,035 & 0,152 & 0,028 \\
\hline \multirow{2}{*}{ ESH (mm/saat) } & rho & $-0,216$ & $-0,289$ & $-0,216$ & $-0,249$ & $-0,249$ & $-0,348$ & $-0,332$ \\
\cline { 2 - 9 } & $\mathrm{p}$ & 0,009 & $<0,001$ & 0,009 & 0,003 & 0,003 & $<0,001$ & $<0,001$ \\
\hline
\end{tabular}

CRP: C-reaktif protein, ESH:eritrosit sedimentesyon hızı. 
tutukluğu olanlara oranla vücut şekil bozukluğu endişesinin daha fazla olduğu ve seksüel tatminsizlik oranının daha yüksek olduğunu vurgulamışlardır.

Çalışmamızda RA'ı kadın hastalarda, SDA Hi skorları arttıkça KSFI'nin alt grup skorları ve toplam skor anlamlı derecede azalıyordu. Sağlık değerlendirme anketi RA'lı hastalarda fonksiyonel yetenek seviyesini değerlendirir. Üst ekstremitenin ince motor hareketlerini, alt ekstremitenin lokomotor aktivitelerini ve hem üst hem alt ekstremiteler ile ilgili değişik aktiviteleri içerir $(15,16)$. Seksüel aktivite üst ve alt ekstremite başta olmak üzere tüm vücudun organize olarak hareketini içeren karmaşık bir eylemdir. Bu nedenle sağlık değerlendirme anketini etkileyen özelliklerin hepsi seksüel disfonksiyona neden olabilir. Sağlık değerlendirme anketindeki skor yüksekliğinin seksüel disfonksiyon ile arasındaki negatif ilişkiyi gösteren yayınlar mevcuttur (36). Regresyon analizleri de yüksek SDA Hi skorlarının seksüel disfonksiyonun özellikle arzu alt parametresini belirgin olarak olumsuz yönde etkilediğini göstermiştir.

Çalışmamızda, RA'ı kadın hastaların eklemlerindeki deformite sayısı, kısıtlı eklem, şiş eklem ve hassas eklem sayısı ve RAl skoru artıkça KSFI'nin alt birimlerinin çoğu ve toplam skorun anlamlı derecede olumsuz etkilendiğini gözlemledik. Bunun beklenen bir sonuç olması gerektiğini düşünmekteyiz. Deformite ve eklemlerdeki kısıtlııı hastanın vücut şeklini değiştirir, hassas ve şiş eklemlerin olması kronik ağrıya neden olur. Ek olarak literatürde, eklem tutulumunun, fiziksel hareket kısıtılığı, vücut şekil bozukluğuna bağlı partnerin ilgisinin kaybı, seksüel ilişki sırasında pozisyondaki güçlükler ve vajinal lubrikasyonun azalmasına bağlı oluşan seksüel disfonksiyonu tetiklediğini bildiren yayınlar vardır $(8,13,30,31)$. Seksüalite beyinde başlayan bir olay olsa da seksüel eylem için eklemlerin sağlıklı olması ve organize hareketi de önem taşımaktadır. Blake ve ark. (30) yaptığı bir çalışmada, şiddetli eklem tutulumu olan RA'lı kadın hastalarda, eklem tutulumu olmayan kadın hastalara göre daha yüksek oranda seksüel disfonksiyon oranları bildirmişlerdir. Bir çalışmada, şiddetli kalça tutulumu sonrası yapılan total kalça replasmanı sonrasında; RA hastalarında seksüel disfonksiyonda \%50'ye yaklaşan iyileşmeler bildirilmiştir (37).

Çalışma grubumuzda değerlendirdiğimiz bir diğer parametre de el kavrama gücü idi. RA hastalarında el kavrama gücü azaldıkça seksüel disfonksiyonun arttığını saptadık. El kavrama gücü hastalık aktivitesinin bir göstergesidir, özellikle el interensek kaslarındaki gücü gösterir, bununla birlikte deformiteler, tutukluk ve ağrıdan da etkilenir ve hastanın günlük aktiviteleri üzerine olumsuz etkiler oluşturur. Bu nedenlerle düşük el kavrama gücünün seksüel disfonksiyona katkısı olasıdır. Benzer şekilde Abdel-Nasser ve ark. (38) yaptıkları çalışmada, el kavrama gücü azaldıkça seksüel disfonksiyonun arttığını rapor etmişlerdir.

Çalışma grubundaki RA hastalarının hastalık aktivitelerini değerlendiren HAS-28 skorları arttıkça KSFI'nin hemen hemen tüm alt birimleri ve toplam skor azalıyordu. HAS-28'in

Tablo 10. Romatoid artrit grubunda radyolojik Larsen skorlamasının kadın seksüel fonksiyon indeksine olan etkisi.

\begin{tabular}{|c|c|c|c|c|c|c|c|c|}
\hline & & Arzu & Uyarılma & Lubrikasyon & Orgazm & Tatmin & Ağrı & Toplam \\
\hline \multirow[t]{2}{*}{ Sağ el } & rho & $-0,204$ & $-0,224$ & $-0,204$ & $-0,261$ & $-0,140$ & $-0,253$ & $-0,277$ \\
\hline & $p$ & 0,043 & 0,026 & 0,043 & 0,009 & 0,168 & 0,012 & 0,006 \\
\hline \multirow[t]{2}{*}{ Sol el } & rho & $-0,252$ & $-0,243$ & $-0,185$ & $-0,347$ & $-0,203$ & $-0,253$ & $-0,310$ \\
\hline & $p$ & 0,012 & 0,015 & 0,067 & $<0,001$ & 0,044 & 0,011 & 0,002 \\
\hline \multirow[t]{2}{*}{ Sağ ayak } & rho & $-0,279$ & $-0,283$ & $-0,327$ & $-0,376$ & $-0,221$ & $-0,283$ & $-0,382$ \\
\hline & $\mathrm{p}$ & 0,005 & 0,005 & $<0,001$ & $<0,001$ & 0,028 & 0,005 & $<0,001$ \\
\hline \multirow[t]{2}{*}{ Sol ayak } & rho & $-0,319$ & $-0,290$ & $-0,324$ & $-0,397$ & $-0,253$ & $-0,300$ & $-0,404$ \\
\hline & $p$ & $<0,001$ & 0,004 & $<0,001$ & $<0,001$ & 0,012 & 0,003 & $<0,001$ \\
\hline \multirow[t]{2}{*}{ Sağ kalça } & rho & $-0,280$ & $-0,247$ & $-0,355$ & $-0,389$ & $-0,298$ & $-0,352$ & $-0,401$ \\
\hline & $p$ & 0,005 & 0,014 & $<0,001$ & $<0,001$ & 0,003 & $<0,001$ & $<0,001$ \\
\hline \multirow[t]{2}{*}{ Sol kalça } & rho & $-0,276$ & $-0,256$ & $-0,327$ & $-0,334$ & $-0,307$ & $-0,315$ & $-0,391$ \\
\hline & $\mathrm{p}$ & 0,006 & 0,011 & $<0,001$ & $<0,001$ & 0,002 & 0,002 & $<0,001$ \\
\hline \multirow[t]{2}{*}{ Sağ diz } & rho & $-0,163$ & $-0,129$ & $-0,309$ & $-0,184$ & $-0,192$ & $-0,226$ & $-0,276$ \\
\hline & $p$ & 0,108 & 0,204 & 0,002 & 0,068 & 0,056 & 0,024 & 0,006 \\
\hline \multirow[t]{2}{*}{ Sol diz } & rho & $-0,201$ & $-0,123$ & $-0,268$ & $-0,216$ & $-0,197$ & $-0,167$ & $-0,263$ \\
\hline & $p$ & 0,046 & 0,225 & 0,007 & 0,032 & 0,050 & 0,099 & 0,009 \\
\hline \multirow[t]{2}{*}{ Toplam } & rho & $-0,281$ & $-0,270$ & $-0,278$ & $-0,381$ & $-0,230$ & $-0,281$ & $-0,366$ \\
\hline & $\mathrm{p}$ & 0,005 & 0,007 & 0,005 & $<0,001$ & 0,022 & 0,005 & $<0,001$ \\
\hline
\end{tabular}


hesaplanmasında kullanılan eritrosit sedimentasyon hızı, şiş eklem sayısı, hassas eklem sayısı ve ağrıyı içeren dört değişkenin de seksüel disfonksiyonu etkilediği bilinmektedir. Yapılan bir çalışmada, RA'lı hastaların hastalık aktiviteleri hastalık aktivite indeksi (index of disease activity; IDA) ile değerlendirilmiş ve hastalık aktiviteleri arttıkça seksüel disfonksiyon oranlarının arttığı rapor edilmiştir (31). Ek olarak, çalışmamızda RA hastalarında laboratuvar aktivite parametrelerinden yüksek eritrosit sedimentasyon hızının KSFI'nin tüm alt birimleri ve toplam skoru, $C$ reaktif protein ise özellikle toplam skoru negatif olarak etkilediğini tespit ettik.

RA'da kadın seksüel disfonksiyonunu değerlendiren daha önceki hiçbir çalışmada hastanın günlük yaşam aktivitelerini değerlendirmede kullanılan ARB FS ile seksüel disfonksiyon arasındaki ilişki değerlendirilmemiştir. Biz çalışmamızda ARB FS'nin yüksek olduğu hastalarda seksüel disfonksiyonun alt parametrelerinin çoğunun ve toplam skorun belirgin olarak azaldığını gözlemledik. Kendine bakım, meslek ve meslek dışı aktivitelerinde kısıtlanmış bir bireyin seksüel yaşantısının olumsuz yönde etkilenmesi beklenen bir sonuçtur. Yaptığımız regresyon analizleri yüksek ARB FS değerlerinin seksüel disfonksiyonun özellikle arzu alt parametresini belirgin olarak olumsuz yönde etkilediğini göstermiştir.

RA grubu kendi içinde jinekolojik açıdan değerlendirildiğinde hastaların menstruasyonunun düzenli olması, düzensiz olması veya postmenopozal olmalarının seksüel disfonksiyon gösterme açısından belirgin bir fark yarattığı gözlenmiştir. Bu sonuç bize, RA'lı kadın hastalarda gelişen seksüel disfonksiyonda depresyon, hastalık aktivitesi, fiziksel dizabilite gibi RA'ya bağlı etkenlerin varlığının yanısıra hormonların etkisinin de göz ardı edilemeyeceğini göstermiştir.

RA grubunda, Larsen skorlamasına göre değerlendirilen radyolojik eklem hasarı total skorları arttıkça KSFI'nin toplam ve alt birim skorlarının hepsinin anlamlı derecede azaldığını tespit ettik. Biz çalışmamızda her iki el, ayak, kalça ve diz eklemlerinin radyolojik skorlarlaması ile KSFI skorlamaları arasında negatif korelasyon tespit ettik. Abdel-Nasser ve ark. (38) kadın RA hastalarında seksüel disfonksiyonu araştıran çalışmalarında kalça ve diz eklemindeki hasarı Steinbrocker radyolojik evrelemesine göre değerlendirmişlerdir. Ve bu

Tablo 11. Romatoid artrit grubunda kadın seksüel fonksiyon indeksi alt skor ve toplam puanı üzerinde etkili olabileceği düşünülen risk faktörlerinin çoklu etkileri.

\begin{tabular}{|c|c|c|c|c|c|c|c|c|c|c|c|c|c|c|}
\hline \multicolumn{3}{|c|}{ Arzu } & \multicolumn{2}{|c|}{ Uyarılma } & \multicolumn{2}{|c|}{ Lubrikasyon } & \multicolumn{2}{|c|}{ Orgazm } & \multicolumn{2}{|c|}{ Tatmin } & \multicolumn{2}{|l|}{ Ağrı } & \multicolumn{2}{|c|}{ Toplam } \\
\hline $\begin{array}{l}\text { Bağımsız } \\
\text { Değişkenler }\end{array}$ & RK (B) & $\mathrm{p}$ & RK (B) & $p$ & $\mathrm{RK}(\mathrm{B})$ & $p$ & RK (B) & $\mathrm{p}$ & RK (B) & $p$ & RK (B) & $\mathrm{p}$ & RK (B) & $p$ \\
\hline Yaş (yıl) & $-0,007$ & 0,121 & $-0,005$ & 0,353 & $-0,010$ & 0,112 & $-0,015$ & 0,017 & $-0,010$ & 0,113 & 0,005 & 0,521 & $-0,011$ & 0,069 \\
\hline $\mathrm{VKI}\left(\mathrm{kg} / \mathrm{m}^{2}\right)$ & $-0,005$ & 0,663 & $-0,015$ & 0,228 & $-0,007$ & 0,609 & $-0,004$ & 0,785 & $-0,008$ & 0,554 & $-0,019$ & 0,228 & $-0,015$ & 0,258 \\
\hline Eğitim & 0,046 & 0,138 & 0,070 & 0,052 & 0,019 & 0,637 & 0,065 & 0,109 & $-0,008$ & 0,853 & 0,028 & 0,541 & 0,009 & 0,817 \\
\hline $\begin{array}{l}\text { Ekonomik } \\
\text { bağımsızlık }\end{array}$ & $-0,096$ & 0,527 & $-0,001$ & 0,997 & 0,131 & 0,510 & 0,138 & 0,486 & 0,134 & 0,501 & 0,233 & 0,309 & 0,141 & 0,456 \\
\hline $\begin{array}{l}\text { Hastalık } \\
\text { süresi }\end{array}$ & $-0,011$ & 0,043 & $-0,010$ & 0,096 & $-0,006$ & 0,372 & $-0,005$ & 0,462 & $-0,003$ & 0,651 & $-0,013$ & 0,110 & $-0,006$ & 0,338 \\
\hline VAS ağrı & $-0,002$ & 0,492 & $-0,001$ & 0,706 & 0,001 & 0,889 & 0,003 & 0,429 & 0,002 & 0,556 & $-0,001$ & 0,733 & $-0,006$ & 0,070 \\
\hline VAS yorgunluk & 0,002 & 0,476 & 0,000 & 0,994 & $-0,002$ & 0,609 & $-0,001$ & 0,689 & $-0,004$ & 0,160 & 0,002 & 0,622 & 0,004 & 0,175 \\
\hline SDA HI & $-0,109$ & 0,029 & 0,012 & 0,827 & $-0,064$ & 0,323 & $-0,020$ & 0,751 & $-0,098$ & 0,133 & $-0,060$ & 0,424 & $-0,046$ & 0,457 \\
\hline BDÖ & $-0,025$ & $<0,001$ & $-0,020$ & $<0,001$ & $-0,010$ & 0,044 & $-0,021$ & $<0,001$ & $-0,021$ & $<0,001$ & $-0,009$ & 0,121 & $-0,017$ & $<0,001$ \\
\hline ARB FS & $-0,200$ & $<0,001$ & $-0,177$ & 0,006 & $-0,020$ & 0,781 & $-0,118$ & 0,101 & 0,019 & 0,789 & $-0,055$ & 0,503 & $-0,033$ & 0,625 \\
\hline HAS-28 & 0,025 & 0,557 & 0,063 & 0,196 & 0,037 & 0,508 & $-0,041$ & 0,459 & $-0,039$ & 0,485 & $-0,010$ & 0,879 & 0,047 & 0,369 \\
\hline $\begin{array}{l}\text { Sağ kalça } \\
\text { radyolojik skoru }\end{array}$ & 0,006 & 0,888 & 0,089 & 0,077 & $-0,044$ & 0,439 & $-0,008$ & 0,891 & 0,069 & 0,228 & $-0,020$ & 0,761 & $-0,082$ & 0,124 \\
\hline $\begin{array}{l}\text { Sol kalça } \\
\text { radyolojik skoru }\end{array}$ & 0,022 & 0,626 & $-0,060$ & 0,243 & $-0,003$ & 0,964 & 0,010 & 0,858 & $-0,072$ & 0,221 & 0,007 & 0,917 & 0,058 & 0,295 \\
\hline
\end{tabular}

RK: Regresyon Katsayısı, VKI: Vücut Kütle Indeksi, BDÖ: Beck Depresyon Ölçeği, SDA Hi: Sağlık Değerlendirme Anketi Hastalık Indeksi, ARB FS: Amerikan Romatizma Birliği Fonksiyonel Sınıfı, VAS: Vizüel Analog Skala, HAS-28: Hastalık Aktivite Skoru-28. 
çalışmada, kalça eklem tutulumu ile seksüel disfonksiyon arasında anlamlı korelasyon gözlenmişken diz eklemi tutulumu ile seksüel disfoksiyon arasında belirgin bir korelasyon gözlenmemiştir. Bizim bulgularımız Abdel-Nasser ve ark.'nın bulgularıyla uyumluydu. Ancak biz kalçalardaki tutulumunun şiddetinin KSFI'nın tüm alt birimlerini etkilediğini, bununla birlikte diz tutulumunun şiddetin KSFI'ın daha az alt parametresini etkilediğini gözlemledik. Hastaların kalça tutulumu belirlendikten sonra fizik tedavi programları ve uygun alet kullanımı ile seksüel disfonksiyonun azaltılabileceğini vurgulayan yayınlar vardır (8).

Bu çalışmada, RA'lı hastalarda ekstraartiküler tutulum olup olmadığı da araştırıldı ve bunların seksüel yaşama etkileri değerlendirildi. Hastaların \%13'ünde akciğer tutulumu vardı. Akciğer tutulumu olan RA hastalarında seksüel arzu, uyarılma, ağrı ve toplam skor, akciğer tutulumu olmayan RA hastalarına göre anlamlı derecede düşüktü. Bu çalışmada akciğer tutulum paternleri ve hastalardaki dispne detaylandırımamış olmakla birlikte, akciğer tutulumunda görülen efor dispnesinin oluşmasından duyulan kaygının seksüel performansı etkilemiş olabileceğini düşünmekteyiz. Öte yandan akciğer tutulumu RA hastalarında hastalık aktivitesinin yüksek olduğuna dair bir göstergedir ve seksüel performanstaki etkilenmenin artmış hastalık aktivitesi nedeniyle olduğu da düşünülebilir. RA'lı kadın hastalarımızın \%9'unda Sjögren sendromu mevcuttu. Sjögren sendromu olan hastalarımızda, kadın seksüel fonksiyon indeksinde sadece lubrikasyon üzerine etkili olduğu ve toplam skoru etkilemediği gözlendi. Sjögren sendromunun vajinal kuruluğa ikincil seksüel disfonksiyon yaptığını destekleyen çalışmalar literatürde mevcuttur $(8,29)$. Değerlendirilen diğer ekstraartiküler bulguların seksüel fonksiyona anlamlı bir etkisi gözlenmedi.

RA hastalarında HMARI kullanımının ve monoterapi veya kombine terapi olarak kullanılmasıyla seksüel disfonksiyon arasında bir ilişki tespit edilmedi. Bizim bulgumuz literatürle uyumluydu (38).

RA'lı hastalar, günlük fonksiyonlarındaki kısıtlanmalara ek olarak sosyal sınırlanmalarla da karşı karşıya kalabilmektedir (39). Hastalığın kronik doğası ve günlük işlevselliği bozan bir özelliğinin olması nedeniyle, hastaların sosyal ilişkilerinde sorunlar oluşmakta bu durum giderek sosyal izolasyona yol açmakta ve bunun sonucunda prognoz daha da kötüleşmektedir. RA'lı hastaların \%40-50'sinde depresif belirti veya depresyon bulunduğu belirtilmektedir (11). Depresif belirtiler gösteren hastaların seksüel açıdan etkilenmeleri olasıdır. Bizim çalışmamızda, regresyon analizi yapıldığında RA'daki kadın seksüel disfonksiyonun ağrı dışındaki tüm alt paremetrelerini ve total skoru olumsuz etkileyen en belirgin faktörün yüksek BDÖ skoru olduğu tespit edilmiştir. Psikolojik stres faktörleri olarak gösterilen depresyon, değişmiş vücut şekli ve partnerin ilgisinin kaybolması endişesinin seksüel fonksiyon bozukluğuna neden olduğu daha önceki çalışmalarda gösterilmiştir $(13,31)$.

Kraaimat ve ark. (40) yaptıkları bir çalışmada, depresyon ve ağrının RA'da seksüel fonksiyon bozukluğuna katkıda bulunduğunu rapor etmişlerdir. Sağlıklı popülasyondaki kadınlarda da depresyonun hem seksüel arzuda kayba (41) hem de seksüel tatminde azalmaya (42) neden olduğu gösterilmiştir. Bizim çalışmamızda da RA grubuna ek olarak kontrol grubunda da BDÖ puanları düşük olan kadınlarda, KSFI'nin negatif yönde etkilendiği görülmüştür.
Depresyon, RA hastalarında yaygın bir problem olup ayrıca ağrı ile belirgin korelasyon göstermektedir (11). Gaskin ve ark. (43) da kronik ağrıya, depresyon, anksiyete ve öfkenin etkisini araştırdıkları bir çalışmada, olumsuz ruh halinin kronik ağrıya eğilim yaratan bir etmen olduğu hipotezinden çok, kronik ağrının ruh halini olumsuz etkilediği hipotezini destekler tarzda veriler bulmuşlardır. Ağıı nedeniyle RA hastalarının daha az cinsel ilişki isteği duyduğunu ve orgazm süresinin kısaldığını bildiren çalışmalar mevcuttur. Şiddetli ağrı, fiziksel dizabilite ve depresyonun seksüel yaşam üzerine önemli derecede olumsuz etkiler yaptığı gösterilmiştir (41). Çalışmamızda bulduğumuz ağrı şiddeti ile KSFI ve BDÖ skorları arasındaki korelasyonlar bu bilgileri doğrular niteliktedir.

Hawley ve Wolfe (44), romatizmal hastalıklarda depresyonun merkezi önemi olduğunu belirterek; ağrı, fonksiyonel yetersizlik, hizmetlerin kullanımında kısıtlılık ve tedavi süresi gibi etmenlerin hepsinin depresyon ile ilişkili olduğunu bildirmişlerdir. Bizim çalışmamızda, depresyonun RA'lı kadın hastalarda seksüel disfonksiyon ile belirgin korelasyon gösterdiği saptanmıştır. Bu sonuç RA'lı kadınlarda depresyonun seksüel arzu, uyarılma, lubrikasyon, orgazm ve tatmini azaltarak seksüel disfonksiyona neden olduğunu düşündürmektedir.

Literatürde; RA ile seksüel disfonksiyon arasındaki ilişkiyi değerlendiren yayınlarda RA ile seksüel disfonksiyon arasındaki korelasyonunun kadınlarda daha zayıf olduğu bildirilmiştir $(32,45)$. $\mathrm{Bu}$ çalışmalarda neden olarak, hastaların fizyolojik durumlarının psikolojik durumlarından bağımsız olduğu, özellikle seksüel tatminin sadece kişisel ve sosyal faktörlere bağımlı olduğu öne sürülmüş̧ür. Erkek hastalarda fiziksel sağlık durumunun ve hastalık aktivitesinin seksüel problemlerle daha çok ilişkili olduğu vurgulanmıştır. Ayrıca kadın faktörünün cinsel ilişki sırasında erkekten daha pasif bir rol oynamasının da bu zayıf korelasyonda etkili olabileceği iddia edilmiştir. Biz çalışmamızda elde ettiğimiz objektif veriler nedeniyle bu görüşe katılmıyoruz. Literatürde RA ve kadın seksüel disfonksiyonunun ilişkisini araştıran çalışmaların çoğu; kontrol grubu olmadan ve hastaların evlerinde postayla gönderilen basit sorgulama formlarına verilen cevaplarla yapılan araştırmalardan elde edilen dar kapsamlı sonuçlar içermektedir. Biz, uzun süredir merkezimizde düzenli olarak takip edilen hastaları hekim rehberliğinde, yüz yüze olarak sorguladık ve kadın seksüel fonksiyon indeksi ile birlikte RA hastalığı ile ilgili muayene ve klinik laboratuvar testlerini de eş zamanlı yapma imkanına sahiptik. Ayrıca daha fazla sayıda hasta ve kontrol bireyini değerlendirmeye aldık. Sonuçta elde ettiğimiz objektif verilerde, daha önce bildirilenin aksine, kadın RA hastalarının fiziksel ve fizyolojik durumlarının psikolojik durumları ile yakından ilişkili olduğunu ve bu durumun seksüel disfonksiyonu belirgin olarak artırdığını saptadık.

RA hastalığının, kadın hastaların seksüel yaşamı üzerine önemli olumsuz etkileri olduğu hem bizim çalışmamızda hem de literatürdeki çalışmalarda vurgulandığı halde; hastalar ve klinisyenler bu konuda konuşmaktan kaçınmaktadır (8). Ingiltere'de yapılan bir çalışmada, 10 romatoloğun hastalarının sadece \%12'sine seksüel yaşamlarılla ilgili sorgulama yaptığı gösterilmiştir (45). Yine RA hastaları üzerinde yapılan bir araştırmada, hastaların \%66'sına seksüel yaşamla ilgili daha önce hiç sorgulama yapılmadığı saptanmıştır (36). Daha muhafazakar ülkelerde ise hastalar özel olarak şikayetleri olmadıkça bu alanda hiçbir sorgulama yapılmadığı bilinmektedir (28). Biz merkezimize uzun 
zamandır takibe gelen hastaların tabu halinde olan bu konuyu konuşmaya istekli olduğunu ve bir çözüm arayışında olduklarını gözlemledik. Seksüel disfonksiyon tedavisinin ilk adımı: kronik hastalığı olan insanların da seksüel olma haklarının var olduğunu ve onlarında seksüel varlıklar olduğunu kavramak ve kabul etmekten geçer. Fiziksel disabiliteye yol açan hastalıkları olan insanlar bu maluliyeti bir de toplumun onları aseksüel saymaları ile daha fazla yaşarlar (46). Dolayısıyla klinisyen ve yardımcı sağlık personelinin seksüel sorgulama, bilgilendirme ve danışmanlık yaklaşımıyla hastalar üzerindeki bu yükün azaltılabileceğini düşünüyoruz.

Biz çalışmamızda, RA'lı kadın hastalarda seksüel disfonksiyonun yoğun olarak yaşandığını gözlemledik. Sonuçta; fiziksel, psikolojik ve sosyal disabiliteye yol açan RA hastalarında seksüel yaşam değerlendirilmesinin klinik değerlendirmenin oldukça önemli bir parçası olduğu ve göz ardı edilmemesi gerektiği görüşüne vardık.

\section{Çıkar Çatışması:}

Yazarlar herhangi bir çıkar çatışması bildirmemişlerdir.

\section{Kaynaklar}

1. Haris ED. Clinical features of rheumatoid arthritis. In: Ruddy $S$, Harris ED,Sledge CB, editors. Kelley's Textbook of Rheumatology. 6th ed. Philadelphia: WB Saunders; 2001. p. 921-67.

2. Wilder RL. Rheumatoid Arthritis, epidemiology, pathology and pathogenesis. In: Schumacher RH, editor. Primer on the Rheumatic Diseases. Arthritis Foundation: Atlanta; 1993. p. 86-9.

3. Silman AJ. Will rheumatoid arthritis still be an important health problem in the 21st centrury. Scand I Rheumatol 2000;29:143-5.

4. Spector IP, Carey MP. Incidence and Prevalence of the sexual dysfunctions: a critical review of the empirical literature. Arc Sex Behav 1990;19:389-408.

5. Kohn IJ, Kaplan SA. Female sexual dysfunction: What is known and what remains to be determined. Contemporary Urology 1999:9:54-72.

6. Rosen RC, Taylor JF, Leiblum SR, Bachmann GA. Prevalence of sexual dysfunction in women: results of a survey study of 329 women in an outpatient gynecologial clinic. I Sex Marital Ther 1993;19:171-88.

7. Duran A, Savrun BM. Rehabilitasyonun Psikolojik Yönü. Oğuz H, Dursun E, Dursun N, editörler. Tıbbi Rehabilitasyon. Nobel Tıp Kitabevleri: Istanbul; 2004. p. 313-31.

8. Yoshino $S$, Uchida $S$. Sexual problems of women with rheumatoid arthritis. Arch Phys Med Rehabil 1982;62:122-3.

9. Berman JR, Berman LA, Werbin TJ, Goldstein I. Female Sexual dysfunction: anatomy, Physiology, evaluation and treatment options. Curr Opin Urol 1999;9:563-8.

10. Gutweniger S, Kopp M, Mur E, Gunther V. Body image of women with rheumatoid arthritis. Clin Exp Rheumatol 17;1999:413-7.

11. Abdel-Nasser AM, Abd El-Azim S, Taal E, El-Badawy SA, Rasker J], Valkenburg HA. Depression and depressive symptoms in rheumatoid arthritis patients: an analysis of their occurrence and determinants. $\mathrm{Br}$ J Rheumatol 1998;37:391-7.

12. Elst P, Sybesma T, van der Stadt RJ, Prins AP, Muller WH, den Butter A. Sexual problems in rheumatoid arthritis and ankylosing spondylitis. Arthritis Rheum 1984:27:217-20.

13. Ehrlich GE. Social, economic, psychologic, and sexual outcomes in rheumatoid arthritis. Am J Med 1983;75:27-34.

14. Hill, , Bird $H$, Thorpe R. Effect of rheumatoid arthritis on sexual activity and relationships. Rheumatology (Oxford) 2003;42:280-6.

15. Bruce $B$, Fries IF, The Stanford health assessment questionnaire: Dimension and pratical spplication. Health Qual Life Outcomes 2003;9;1:20

16. Bruce B, Fries JF. The Health Assessment Questionnaire (HAQ). Clin Exp Rheumatol 2005; 23(5 Suppl 39):14-8.

17. Ritchie DM, Boyle JA, Mclnnes IM, Jasani MK, Dalakos TG, Grieveson P, et al. Clinical studies with an articular index for the assessment of joint tenderness in patients with rheumatoid arthritis. Q J Med 1968;37:393406.
18. Akıncı A. Aktivite ve fonksiyonel değerlendirme. Hamuryudan V, editör Romatoid Artrit. MD Yayıncllk; Ankara: 2002. p. 65-71.

19. Smolen IS, Breedveld FC, Schiff MH, Kalden IR, Emery P, Eberl P, et al. A simplified disease activity index for rheumatoid arthritis for use in clinical practice. Rheumatology (Oxford) 2003;42:244-57.

20. Larsen A, Dale K, Eek M. Radiographic evaluation of rheumatoid arthritis and related conditions by standard reference films. Acta Radiol Diagn (Stockh) 1977;18:481-91.

21. Wiegel M, Meston C, Rosen R. The female sexual function index (FSFI): cross-validation and development of clinical cutoff scores. I Sex Marital Ther 2005;31:1-20.

22. Hisli N. Beck depresyon envanterinin geçerliliği üzerine bir çalıșma. Psikoloji Dergisi 1988;22:118-26.

23. Serrant-Green L. Ineguality in provision of sexual health information. Prof Nurse 2001;16:1038-42.

24. Irwin R. Sexual health promotion in nursing. J Adv Nurs 1997;25:170-7.

25. Law C. Sexual health and the respiratory patient. Nurs Times 2001;97:11-2.

26. Freud A. The ego and mechanims of defens. London: Hogart Press, 1936

27. Pitts M. Sexual health: The psychology of preventative health. London: Routledge; 1996.

28. Lawrence R. Rheumatoid arthritis: classfication and epidemiology. In: Klippel JH, Dieppe PA, editors. Rheumatology. St Louis: Mosby; 1994. p. 3.1-4.

29. Bhadauria S, Moser DK, Clements PJ, Singh RR, Lachenbruch PA, Pitkin RM, et al. Genital tract abnormalities and female sexual function impairment in systemic sclerosis. Am J Obstet Gynecol 1995;172:580-7.

30. Blake DJ, Maisiak R, Alarcon GS, Holley HL, Brown S. Sexual quality-of-life of patients with arthritis compared to arthritis-free controls. J Rheumatol 1987; 14:570-6.

31. Blake DJ, Maisiak R, Koplan A, Alarcon GS, Brown S. Sexual dysfunction among patients with arthritis. Clin Rheumatol 1988;7:50-60.

32. van Berlo WT, van de Wiel HB, Taal E, Rasker II, Weijmar Schultz WC, van Rijswijk MH. Sexual functioning of people with rheumatoid arthritis: a multicenter study. Clin Rheumatol 2007;26:30-8.

33. Kinsey AC, Pomery WB, Martin CE. Sexual behavior in the human female. Philedelphia, Pa: WB Saunders Co; 1948.

34. Laumann EO, Gagnon JH, Michael RT, Michaels S. The social organization of sexualty: Sexualty practices in the United States: Chicago press, 1994.

35. Symmons DP. Epidemiology of rheumatoid arthritis: determinants of onset, persistence and outcome. Best Pract Res Clin Rheumatol 2002; 16:707-22

36. Ferguson K, Figley B. Sexuality and rheumatic disease: a prospective study. Sex Disabil 1979;2:130-8.

37. Yoshino S, Fujimori J, Morishige T, Uchida S. Bilateral joint replacement of hip and knee joints in patients with rheumatoid arthritis. Arch Orthop Trauma Surg 1984;103:1-4.

38. Abdel-Nasser AM, Ali El. Determinants of sexual disability and dissatisfaction in female patients with rheumatoid arthritis. Clin Rheumatol 2006;25:822-30.

39. Krol B, Sanderman R, Suurmeijer T, Doeglas D, van Rijswijk $M$, van Leeuwen M. Disease characteristics. Level of self-esteem, and psychological well-being in rheumatoid artritis patients. Scand J Rheumatol 1994;23:8-12.

40. Kraaimaat FW, Bakker AH, Janssen E, Bijlsma JW. Intrusiveness of rheumatoid arthritis on sexuality in male and female patients living with a spouse. Arthritis Care Res 1996;9:120-5.

41. Channon LD, Ballinger SE. Some aspects of sexuality and vaginal symptoms during menopause and their relation to anxiety and depression. Br J Med Psychol 1986;59:173-80.

42. Frohlich P, Meston C. Sexual functioning and selfreported depressive symptoms among college women. J Sex Res 2002;39:321-5.

43. Gaskin ME, Greene AF, Robinson ME, Geisser ME. Negative affect and the experience of chronic pain. J Psychosom Res 1992;36:707-13.

44. Hawley DJ, Wolfe F. Depression is not more common in rheumatoid arthritis: a 10-year longitudinal study of 6,153 patients with rheumatic disease. J RJ Rheumatol 1993;20:2025-31

45. Britto MT, Rosenthal SL, Taylor I, Passo MH. Improving rheumatologists screening for alcohol use and sexual activity. Arch Pediatr Adolesc Med 2000:154:478-83.

46. Comfort A. Foreword. In: Mooney TO, Cole TM, Chilgren RA,editors. Sexual options for paraplegics and tetraplegics. Boston: Little Brown Company; 1975. 